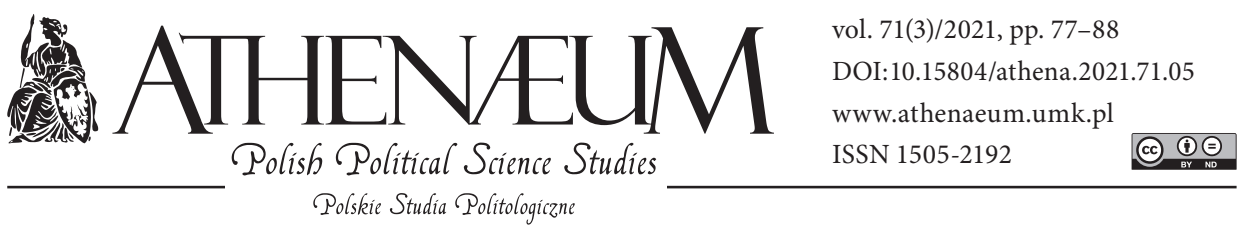

\title{
DECREASING THE RETIREMENT AGE IN THE VIEW OF DYNAMICALLY AGEING POPULATION IN POLAND
}

\author{
OBNIŻENIE WIEKU EMERYTALNEGO WOBEC DYNAMICZNIE \\ STARZEJĄCEJ SIĘ POPULACJI W POLSCE
}

Rafał Iwański* (0), Łukasz Tomczak** (0), Agnieszka Lipska-Sondecka*** (1)

\begin{abstract}
- ABSTRACT
The aim of the article is to present expectations and attitudes of Polish society towards the retirement age. The problem is crucial due to dynamic ageing of population. The research was conducted on a national research sample with calculations based on stratified quota sampling. The research was conducted in 2019 on a sample of $n=2088$ respondents. Despite the ageing population, the majority of respondents believe that the age entitling to retirement benefits should not be higher than 60 years for women and 65 for men. Residents of larger cities and respondents with higher earnings supported a higher retirement age. Respondents stated that the most significant factor influencing the amount of retirement benefits is job seniority and the amount of contributions to retirement pension schemes, not the condition of Polish and world economy.
\end{abstract}

Celem artykułu jest przedstawienie oczekiwań i postaw społeczeństwa polskiego wobec wieku emerytalnego. Problem jest istotny ze względu na dynamiczne starzenie się populacji. Badania przeprowadzono na ogólnopolskiej próbie badawczej, opartej o dobór kwotowo-warstwowy. Badanie przeprowadzono w 2019 roku na próbie $\mathrm{n}=2088$ respondentów. Mimo starzenia się społeczeństwa większość respondentów uznała, że wiek uprawniający do emerytury nie powinien przekraczać 60 lat dla kobiet i 65 lat dla mężczyzn. Mieszkańcy większych miast i respondenci o wyższych zarobkach opowiadali się za wyższym wiekiem emerytalnym. Respondenci wskazywali, że najważniejszym czynnikiem wpływającym na wysokość świadczeń emerytalnych jest staż pracy i wysokość składek na emerytury, a nie stan gospodarki polskiej i światowej. Przedstawione wyniki są niezwykle istotne dla obecnych i przy-

* University of Szczecin, Faculty of Social Science.

** University of Szczecin, Faculty of Social Science.

$\star * \star$ University of Szczecin, Faculty of Social Science. 
The presented results are extremely important for current and future rulers due to the design of changes in the scope of retirement benefits.

Keywords: pension system; social insurance; retirement security szłych rządzących ze względu na projektowanie zmian w zakresie świadczeń emerytalnych.

Słowa kluczowe: system emerytalny; ubezpieczenie społeczne; ubezpieczenie emerytalne

\section{INTRODUCTION}

There is a public debate within the majority of the European Union countries about the retirement schemes in the view of ageing population. It is postulated to include in the retirement schemes the fact that Europeans live longer and in better health. The European Union countries have different pension models which are mostly based on multi-pillar structure (Schludi, 2005). However, none of the European Union countries is able to protect future generations from retirement poverty effectively. Having regard to the increase of the average life expectancy, the decrease in fertility rates, and the growing debt of the euro area, most of them decided to implement reforms (Hansen \& Gordon, 2014). Their main goal is to increase the stability of pension schemes through, i.a., a gradual increase of retirement age (Bednarczyk, 2015). The reforms included the increase in the share of retirement benefits other than the state ones, which would secure a relative financial stability of pension scheme and pensions payable (Hassel, Naczyk, \& Wiss, 2019).

Under present demographic-economic conditions, the reform of pension schemes is inevitable due to ageing society, unfavorable demographic forecasts for the future, as well as the already observed government deficit resulting from the need to finance benefits for people who are in the system. Every pension model, no matter how construed, operates by way of generating financial obligations for the future (Hausner, 2008, p. 178). Therefore, every change in pension scheme should form such relations among its particular elements as to protect future generations from retirement poverty (Holzmann \& Hinz, 2005). As the number of people entitled to retirement benefits increases, the government's obligations towards the citizens will also rise.

The aim of the article is to present the attitudes of respondents in terms of the preferred age entitling to retirement benefits for women and men, and the age at which they intend to end their professional activity. Moreover, the respondents were asked to determine what influences the amount of retirement benefits. 
The following research problem was formulated: are there dependencies between the expected age entitling to retirement benefits and the respondents' sex, place of residence, age, education, and income? The following research hypotheses were adopted:

H1: There is a dependency between the respondents' age and the preferred retirement age.

$\mathrm{H} 2$ : The place of residence is connected with the preferred retirement age.

H3: There is a dependency between income and preferred retirement age.

H4: There are differences between the expected age entitling to retirement benefits and education.

The verification of the adopted statements is based on the results of own research, conducted in 2019 in Poland on a sample of $n=2088$ respondents. The stratified quota sampling method was applied in the research sample selection.

The current pension benefits model in Poland is based on a mechanism of defined contribution, with a possibility to join occupational or personal schemes. There are subjective (e.g., pensions for the uniformed services) and objective (minimum pension) exemptions from the basic rule concerning monthly pension contributions. The mechanism of pension benefits designed this way already fails to cope with the burden of financial obligations for people entitled to benefits.

Despite dynamically ageing population and unfavorable demographic forecasts, a reform decreasing the age entitling to retire was introduced in 2018.

\section{DEMOGRAPHIC TRENDS AND PENSION SCHEMES REFORMS}

Poland is one of the countries where the number, and therefore the share, of seniors in the population increases. In 2018, people aged over 65 constituted $17,5 \%$ of population, including $4,3 \%$ aged 80 or over (GUS, 2019). Demographic forecasts indicate that by 2030 , the share of seniors in the population will have increased to $23,2 \%$, and in 2050 it will reach $32,7 \%$. In 2030, people over 80 years old will constitute $5,9 \%$ of population in Poland, and in 2050, as many as $10,4 \%$ (GUS, 2014). In comparison to other EU countries, in 2018 the share of people aged 65 or over was lower than the average for the contries in the Community, which was $19,7 \%$. It is estimated that by 2030 , seniors in the EU countries will have constituted 23,8\%, and in $2050-28,5 \%$ (Eurostat, 2019). In the case of Poland, apart from a dynamic increase of the elderly, the process of depopulation 
will be another important issue. At the end of the second decade of the $21^{\text {st }}$ century Poland had a population of 38,4 million people. In the middle of the century the number will decrease to 33,9 million people (GUS, 2014) (2019).

In Poland, in the first quarter of 2020 the benefits from social security system were collected by 9,3 million people, including 6,9 million people who collected pensions, and 2,4 million people collecting disability or family allowance pensions (GUS, 2020). The average pension was circa 2395 PLN (528€) ${ }^{1}$. There is a noticable difference in the scope of benefits collected by women, which was about 2002 PLN (441€) and men 2992 PLN (660€) (ZUS, 2020). In the case of disability pensions, their average height in 2019 was about 1867 PLN (412€), and family allowance pensions - 2079 PLN (458€) (GUS, 2020). Demographic forecasts estimate that in 2050 in Poland there will be over 12,4 million people entitled to collect pension benefits, and the number of people of working age will decrease compared to 2020 by $27 \%$ and reach 16,5 million (GUS, 2014). It means that in the coming years there will be a shift in relations between economically active group and the group of people at the retirement age.

In the $1990^{\mathrm{s}}$ in Poland, a decision was made to implement a reform in pension scheme. Its main objective was to change the way of calculating the pension based on the capital raised from contributions and establish three subsystems. The first mandatory subsystem raised funds by a state insurer. The second one, also mandatory, consisted of open pension funds chosen by the insured, and the state insurer transferred a part of contributions. The third pillar comprised private pension accounts which were not obligatory. Up to the reform from 1999, pension was calculated based on 10 best years of the contribution period, and the system operated according to pay-as-you-go principles. The reform assumed that the amount of the future pension will be dependent on the raised capital and it will be divided by forecasted life expectancy. The reform was implemented in stages, and covered particular generations. After the pension reform from 1999, the age entitling to retirement for men (65 years) and women (60 years) was maintained (excluding special subsystems, i.a., for farmers, uniformed services, etc.) (Piotrowski, 1999). In 2013, due to dynamically ageing population and extending life expectancy, another reform was introduced. Its main objective was to increase the age entitling to pension benefits to 67 years for both sexes. Its implementation was also divided into stages. It is worth emphasizing that

\footnotetext{
1 The average euro exchange rate in January 2021 was about 4.50 PLN.
} 
the increase of the retirement age did not have public support. According to the research conducted by CBOS (the Public Opinion Research Center in Poland) in April 2012, the reform was not supported by $79 \%$ of men and $86 \%$ of women. In 2017, the governing coalition decided to withdraw the reform and reactivate the previous retirement age entitling to benefits, i.e., 60 years for women and 65 for men.

Currently, there is one main pension scheme in Poland which provides 5,9 million people with benefits, and a few so-called special systems, e.g., for farmers or uniformed services. It is worth mentioning that in the case of the latter, the pension does not depend on the pension contributions made in the period of economic activity.

In order to collect minimum benefit one must work at least 25 years in the case of men, and 20 years in the case of women (ZUS, 2019). Most commonly the lowest benefits are collected by women who have shorter work period. Due to the fact that the Polish live longer, and the retirement age has not been increased, it is expected that in the coming years the average pension benefits will decrease. According to Malec and Tyrowicz's forecasts (2017, p. 30), a half of pensioners will receive the minimum benefits, and when people born in the $1980^{\mathrm{s}}$ and $1990^{\mathrm{s}}$ reach retirement age, the minimum benefits will go to $70 \%$ of Polish pensioners.

In the European Union countries (Germany, Denmark, Italy) there is also a debate on the need to reform pension schemes. The Danish pension scheme is constituted of three pillars: state pension, workplace pension, and private pension savings. The pension scheme designed this way was considered in 2016 as the most appropriate to needs and social expectations, public finances' capacity and demographic challenges by Melbourne Mercer Global Pension Index (Andersen, 2016). The retirement age for the Danish is currently 65 years for men and women, but by 2030 it will have increased to 68 years, and then to 74 years, due to the fact that it is estimated on the average life expectancy (OECD, 2017).

The most important pillar of pension scheme in Germany is the so-called statutory system, ensuring pensions connected with income. In addition to this, there are also workplace and private pension schemes. This model is also considered an exemplary pension scheme which will allow to secure benefits for the current and future beneficiaries (Hinrichs, 2003). The retirement age in Germany from 2031 will be 67 years for both sexes. The exception to this rule will be people who have 45 years of work period, in which case the retirement age will be reached at the age of 65 . 
Also Italy has a pension model based on a few pillars, which allow the diversification of the burden on public finances. The Italian system consists of the following elements: benefits for employed persons, self-employed persons, public officials, selected professional groups (e.g., uniformed services). In addition, there is the so-called social cheque for people who turned 65 years old and do not have sufficient resources received from one of the pension pillars (Schludi, 2005).

Nevertheless, none of the implemented solutions is sufficient to effectively secure the provision of benefits for future generations of pensioners. The ageing population, changes in the labor markets and budget problems impose the need for further changes. The solutions most commonly used are, for instance, increasing the retirement age, promoting a gradual retirement, depending benefits on the contribution period, reducing early retirement, or modifying the methods of benefits financing (Walker, 1997). All these actions aim at preventing the financial crisis of pension schemes which, without appropriate actions taken by the government, will not be able to carry the burden of pension benefits. The basis of their financial solvency is the economic performance, which means that pension reforms need to be designed in a way as to contribute to the greatest extent possible to form effective and competitive economy.

\section{SOCIAL ATTITUDES IN THE POLISH SOCIETY TOWARDS DECREASING THE RETIREMENT AGE IN THE VIEW OF OWN RESEARCH}

The research sample was calculated on $\mathrm{n}=1067$ respondents for the population of 38,4 milion Polish residents with a confidence level of 95\%, 0,05 fraction and maximum error of $3 \%$. In order to eliminate measurement errors, the research sample was doubled and reached the total of $n=2088$ respondents.

The stratified quota sampling method was applied in the research. The size of a sample was calculated for each of 16 provinces in the country considering the distribution with regard to age (6 categories), place of residence (city/village) and sex, based on the demographic data from Statistics Poland (GUS) for 2018. The pollsters, while selecting respondents in their areas, used the research implementation card with a specified number of respondents in a given group on grounds of sex, age and place of residence.

The research was conducted basing on the author's questionnaire survey. The tests of statistical significance are of nonparametric nature. In order to verify assumptions on the materiality of differences between the medians of the 
researched variable, the Mann-Whitney $U$ test was applied, one of the variables had only two groups, as well as the Kruskal-Wallis test for variables of nonsignificant number of categories (education, age categories, income, place of residence). The analysis was performed with Statistica 13 software.

In terms of socio-demographic characteristics of the research, the group reflects proportions of general population of Poland calculated based on the data from the Statistics Poland (GUS) for 2018. Women constituted 52,1\% of the respondents, men $47,9 \%$. In terms of age structure of the respondents, people aged between $18-24$ constituted $9,7 \%$ of the respondents, $25-34$ years $18,1 \%$, $35-44$ years $19,2 \%, 45-54$ years $15,3 \%, 55-64$ years $17,3 \%$, and 65 and more years $20,4 \%$. The residents of villages formed $39,5 \%$ of the respondents, and the residents of cities $60,5 \%$. The respondents with higher education constituted $42,3 \%$, in this case there was $12 \%$ overrepresentation in this category. There were $37,1 \%$ of the respondents with secondary education, and $20,7 \%$ with low education level.

The respondents were asked to determine what should be the age entitling to pension benefits for each sex (Table 1). In the case of the retirement age for men, $42,4 \%$ of the respondents indicated 65 years of age, and 9,5\% think that the pension right should apply at the age of 67 . The economic age limit at the level of 70 years old was indicated by $2,6 \%$ of the respondents, and higher - only $0,5 \%$. Over one third of the respondents think that men should be entitled to pension benefits at the age of 60 , and $10,8 \%$ think that even under 60 years of age. The Mann-Whitney $U$ test carried out for variable sex did not show any statistically significant differences in the distribution of responses. The Kruskal-Wallis test was conducted for variables with a bigger number of categories. In the case of age, the statistically significant difference was noted in the distribution of responses $(\mathrm{H}(6, \mathrm{~N}=2088)=54,73006 \mathrm{p}=, 0000)$. Younger respondents indicated a lower age entitling to pension, in the age groups 18-24 years, $25-34$ years, 35-44 years and $45-54$ years nearly $50 \%$ of the respondents indicated 60 years of age, in the age group 55-64 years it was $41,8 \%$, and in the oldest age group of 65 and over $-30,7 \%$. The distribution of responses is also statistically significant in terms of the place of residence $(\mathrm{H}(6, \mathrm{~N}=2088)=43,57498 \mathrm{p}=, 0000)$. The residents of rural areas of agricultural nature indicated a lower age entitling to benefits, $52,1 \%$ determined it to be 60 years of age or less. In the case of residents of cities with 500,000 inhabitants such responses were given by $33,3 \%$ of the respondents. In the case of education $(\mathrm{H}(3, \mathrm{~N}=2049)=29,36731 \mathrm{p}=, 0000)$, four levels were adpoted: primary, vocational, secondary, and higher. $39,1 \%$ of the respondents 
with higher education and $40,4 \%$ with primary education determined the retirement age for 60 years or less. However, the respondents with vocational and secondary education, respectively $50,7 \%$ and $48,9 \%$. Another significant variable was income $(\mathrm{H}(4, \mathrm{~N}=2054)=40,24246 \mathrm{p}=, 0000)$. In the case of this variable, the lower the income, the bigger the support for the early retirement. People who earned the least $(57,9 \%)$ pointed the age of 60 or less, whereas the group of people with the highest earnings $(37,1 \%$ of the respondents) indicated a higher retirement age.

Table 1. The Age Entitling to Pension Benefits in the Respondents' Opinion for Men and Women

\begin{tabular}{|c|c|c|c|c|}
\hline \multirow{3}{*}{ Responses } & \multicolumn{4}{|c|}{ What do you think should be the age entitling to pension benefits? } \\
\hline & \multicolumn{2}{|c|}{ For men } & \multicolumn{2}{|c|}{ For women } \\
\hline & $\mathrm{n}=2088$ & $\%$ & $\mathrm{n}=2086$ & $\%$ \\
\hline less than 60 years old & 225 & 10,8 & 672 & 32,2 \\
\hline 60 years old & 715 & 34,2 & 950 & 45,5 \\
\hline 65 years old & 885 & 42,4 & 361 & 17,3 \\
\hline 67 years old & 199 & 9,5 & 74 & 3,5 \\
\hline 70 years old & 54 & 2,6 & 21 & 1,0 \\
\hline more than 70 years old & 10 & 0,5 & 8 & 0,4 \\
\hline
\end{tabular}

In the case of retirement age for women, $32,2 \%$ of all the respondents indicate that women should be entitled to pension benefits before the $60^{\text {th }}$ birthday. Nearly a half $(45,5 \%)$ supports the current retirement age, i.e., 60 years of age. $17,3 \%$ believe that the retirement age for women should equal the retirement age for men, only $3,5 \%$ pointed the age 67 , and 1,4\% higher age. In the case of the retirement age for women, the Mann-Whitney test indicated that the distribution of responses between the sexes is statistically significant $(\mathrm{p}<0.001)$. Men slightly more often indicated a higher age entitling to pension benefits for women. The Kruskal-Wallis test did not note any statistically significant distribution of responses in particular age categories in terms of the variable age category. However, when it comes to the place of residence $(\mathrm{H}(6, \mathrm{~N}=2086)$ $=85,21055 \mathrm{p}=, 0000), 82,4 \%$ of the respondents stated that women should have a right to early retirement at the age of 60 at the latest. It is noticeable that in larger cities the support for a higher retirement age is rising. In the case of cities with 200,000 inhabitants, the retirement age of 60 years old is supported by 
$78,1 \%$, in the cities up to 500,000 inhabitants $-72,5 \%$, and in cities with over 500,000 inhabitants $-63,2 \%$. In the case of variable education $(\mathrm{H}(3, \mathrm{~N}=2047)$ $=45,22398 \mathrm{p}=, 0000), 80,8 \%$ of the respondents with primary education and $86 \%$ with vocational education support the current retirement age, i.e., 60 years of age for women. In the group of respondents with secondary education, the support accounts to $78,9 \%$, and with higher education $-70,1 \%$. The lower the income, the greater support for the retirement age at 60 or earlier $(\mathrm{H}(4, \mathrm{~N}=$ $2052)=79,67871 \mathrm{p}=, 0000)$. The group of respondents with the lowest income show support of $87,1 \%$, and it gradually decreases, and in the group of the most paid workers the support is $61,1 \%$.

The respondents also declared when they plan to retire or when they retired. The average was 62,2 years old $(S D=5,3)$. Only in the age category 65 or more, the average reached the level of 63,8 years old $(S D=5,9)$, whilst among respondents of the youngest age category (18-24) the lowest average was observed - 61,0 years old $(S D=6,4)$.

In the next survey the respondents determined what is pension dependent on. Their task was to rank the answers on the scale from one to five, where one means the most important factor, and five the least important one. The work period was considered the most significant factor influencing pensions $(\mathrm{m}=$ $1,95 \mathrm{SD}=1,26) .43,1 \%$ pointed that years of working experience determine the amount of pension. The second position was occupied by the factor connected with the income and contributions made (which constitute a constant percentage of income in Poland). $42 \%$ of the respondents shared this opinion ( $\mathrm{m}=1,92 \mathrm{SD}$ $=1,04)$. Around $9 \%$ of the respondents chose the condition of Polish economy $(\mathrm{m}=3,04 \mathrm{SD}=0,97) .5,7 \%$ of the respondents indicated the link between the pension and the demographic situation $(m=3,57 \mathrm{SD}=0,98)$. Whereas the condition of the world economy was chosen the least frequently as a dominant factor $(\mathrm{m}=4,4 \mathrm{SD}=1,12)$.

\section{CONCLUSIONS}

Ageing of European societies, the early retirement, as well as retirement rights of particular professional groups contributed to already unfavorable changes in relations between people of working age and a group of people at the retirement age. The presented research showed that the respondents are aware that the pension depends on the work period and the contributions made, however, they opt 
for a lower threshold of economic old age at the same time. What is more, people with lower income supported early retirement. As if they were unaware of future problems, in their case in particular, with receiving pensions at the level that is sufficient for a dignified life. The problem with acceptance of necessary changes in the pension scheme is connected with education. The better the education, the more understanding for a higher retirement age.

The respondents also chose a lower retirement age for women. However, the economic forecasts indicate that women will suffer most due to the decrease in the retirement age. As a result of a short work period and relatively long life expectancy, their pension will be around the minimum pension, as provided by law, which is additionally subject to income taxation. Also, the number of people with no pension entitlements or a pension lower than the minimum, is increasing in Poland, and women also predominate in this group.

Funded as well as pay-as-you-go pension schemes will encounter a number of obstacles in the coming years, including demographic issues connected with population ageing processes and the decrease in the number of working-age people (Bednarczyk, 2015). Increasing the retirement age is vital if we intend to maintain, however limited in its scope, the current pension scheme. It is forced by demography and economic balance (Szczepański, 2016), and particularly because the results of the research show that the Polish do not tend to save for retirement (Perek-Białas, 2017).

The decision to increase the retirement age is of political significance. Nevertheless, the ruling parties postpone it due to a negative public opinion. The threat of losing power as a result of lost election may delay the decision-making process. The decision to increase the retirement age should be preceded with a long debate of educational significance. Such actions should be directed especially towards people with lower education and the residents of smaller towns and villages.

\section{REFERENCES:}

Andersen, J.G. (2016). The Danish Pension System. Aalborg: ESPN, Aalborg University. Retrieved from: https://www.politics-society.aau.dk/digitalAssets/661/661770_ goul-andersen-danish-pension-system.short-paper.2016.pdf.

Bednarczyk, T.H. (2015). Wyzwania demograficzne dla systemów emerytalnych w Unii Europejskiej. Annales Mariae Curie-Skłodowska Lublin-Polonia, 49(2), 33-50. DOI: 10.17951/h.2015.59.2.33. 
CBOS (2012, April). Nadal nieprzekonani - Polacy o podwyższeniu wieku emerytalnego. Warszawa: Centrum Badania Opinii Społecznej. Retrieved from: https://www.cbos. pl/SPISKOM.POL/2012/K_057_12.PDF.

Eurostat (2019). Demographic Balances and Indicators by Type of Projection. Retrieved from: https://ec.europa.eu/eurostat/web/population-demography-migrationprojections/data/database.

GUS (2014). Prognoza ludności na lata 2014-2050. Warszawa: Główny Urząd Statystyczny.

GUS (2014). Sytuacja demograficzna osób starszych i konsekwencje starzenia się ludności Polski w świetle prognozy na lata 2014-2050. Warszawa: Główny Urząd Statystyczny. GUS (2018, December 28). Rocznik Statystyczny Rzeczypospolitej Polskiej 2018. Warszawa: Główny Urząd Statystyczny.

GUS (2019). Rocznik demograficzny. Demographic Yearbook of Poland. Warszawa: Główny Urząd Statystyczny.

GUS (2020, November 16). Emerytury i renty w 2019 r. Warszawa: Główny Urząd Statystyczny.

Hansen, R., \& Gordon, J.C. (2014). Deficits, Democracy and Demographics: Europe's Three Crises. West European Politics, 37(6), 1199-1222. DOI: 10.1080/01402382.2014.929336.

Hassel, A., Naczyk, M., \& Wiss, T. (2019). The Political Economy of Pension Financialisation: Public Policy Responses to the Crisis. Journal of European Public Policy, 26(4), 483-500. DOI: 10.1080/13501763.2019.1575455.

Hausner, J. (2008). Zarządzanie publiczne. Warszawa: Scholar.

Hinrichs, K. (2003, December 5). The Politics of Pension Reform in Germany. Paper prepared for the Conference "Pension Reform in Europe: Shared Problems, Sharing Solutions?". London: London School of Economics, Hellenic Observatory/The European Institute.

Holzmann, R., \& Hinz, R.P. (2005). Old Age Income Support in the $21^{\text {st }}$ Century: An International Perspective on Pension Systems and Reform. Washington, D.C.: The World Bank.

Malec, M., \& Tyrowicz, J. (2017). Niski wiek emerytalny, wysoka cena. In: P. Lewandowski, \& J. Rutkowski (Eds.), Starzenie się ludności, rynek pracy i finanse publiczne w Polsce (pp. 29-34). Warszawa: Przedstawicielstwo Komisji Europejskiej w Polsce.

NBP (2021). Kursy średnie walut obcych. Retrived from: https://www.nbp.pl/home. aspx?f=/kursy/kursya.html.

OECD (2017). Pension at a Glance 2017: OECD and G20 Indicators. Paris: OECD Publishing. DOI: 10.1787/pension_glance-2017-en.

Perek-Białas, J. (2017). Zaufanie obywateli do systemu emerytalnego a skłonność do oszczędzania na starość. Ubezpieczenia Społeczne: Teoria i praktyka, 2, 75-93.

Piotrowski, W. (1999). Niektóre aspekty prawne reformy systemu emerytalnego. Ruch Prawniczy, Ekonomiczny i Socjologiczny, 61(1), 147-165. 
Schludi, M. (2005). The Reform of Bismarckian Pension Systems: A Comparison of Pension Politics in Austria, France, Germany, Italy and Sweden. Amsterdam: Amsterdam University Press.

Szczepański, M. (2016). Analiza i ocena proponowanych zmian ustawowego wieku emerytalnego w Polsce. Finanse, Rynki Finansowe, Ubezpieczenia, 79, 739-751.

ZUS (2019). Struktura wysokości emerytur po waloryzacji w marcu.Portal Statystyczny ZUS. Retrieved January 4, 2020 from: https://psz.zus.pl/kategorie/emerytury/ struktura-wysokosci-emerytur-po-waloryzacji-w-marcu.

ZUS (2020). Struktura wysokości świadczeń wypłacanych przez ZUS po waloryzacji w marcu 2020 roku. Warszawa: Zakład Ubezpieczeń Społecznych. Retrieved from: https://www.zus.pl/documents/10182/39637/Struktura+wysoko\%C5\%9Bci+\%C5 \%9Bwiadcze\%C5\%84+wyp\%C5\%82acanych+przez+ZUS+po+waloryzacji+w+m arcu+2020+r.pdf/3df99481-587f-8efe-8f1f-a77871e4f8c8. 